\title{
EMOTIONAL TAGGING AND BELIEF FORMATION - THE LONG-LASTING EFFECTS OF EXPERIENCING COMMUNISM
}

\author{
By Christine Laudenbach, Ulrike Malmendier, And AleXANDRA NiESSEN-RuenZI*
}

\begin{abstract}
*Laudenbach: Goethe University Frankfurt, laudenbach@finance.uni-frankfurt.de. Malmendier: University of California, Berkley, ulrike@berkeley.edu, Niessen-Ruenzi: University of Mannheim, niessen@uni-mannheim.de.
\end{abstract}

The rational beliefs paradigm has long faced empirical criticism from experimental and microeconomics. Macro-finance evidence also suggests that we need to modify the Bayesian model to capture empirical regularities about, e.g., stock market participation, inflation expectations, or consumption.

A key observation is that, compared to Bayesian updaters, individuals overweigh events that are easily remembered. This includes recency bias, i.e., people neglecting realizations that occurred too far in the past (e.g., Fuster, Laibson, Mendel (2010); Barberis, Greenwood, Jin, Shleifer (2018), building on Tversky and Kahnemann (1974)). More generally, though, the literature on experience effects, shows that not only recent, but any personally experienced realizations appear to have long-lasting effects on beliefs, e.g., stock market crash or hyperinflation experienced in the past (Malmendier and Nagel $(2011,2016))$.

The mechanism underlying the overweighing of experiences that are easily available is not yet well understood. Given that the effects are long-lasting, and also found in highly-educated, well-informed individuals (Malmendier, Nagel, Yan, 2018), it seems unlikely that they are due to simple cognitive mistakes that could be undone with financial literacy training or education in Bayesian updating.

Rather, we need to turn to the neurological foundations of memory formation to understand under which circumstances experiences are stored permanently in memory. We propose that emotional tagging plays a crucial role in assigning weights in the belief formation process, and ultimately affecting people's behavior.

A large literature in neuroscience posits that the personal, emotional experience of an outcome alters the "hardware" and thus the functioning of our brain, irrespective of our cognitive abilities (for an overview, see Moncada et al. (2015)). According to the Synaptic Tagging and Capture hypothesis (Frey and Morris (1997)), local tagging of synapses at the moment an experience is made leads to a more stable connection between synapses and eventually memory of the experience. Emotional 
arousal enhances this tagging as it signals to the brain whether an experience is important and should be memorized (LaBar and Cabeza (2006)). The more intense the emotional arousal, the stronger the anchoring of an experience in memory, and the easier its availability in the future (Talarico et al (2004)). Emotional tagging refers to the transfer of an experience into memory as a function of its emotional significance (Richter-Levin and Akirav (2003)). It works similarly for positive and negative experiences (Hamann et al. (1999)).

Applying these insights to economic decision making, we need to know more than past realizations and informational constraints to understand people's beliefs and future behaviors. It matters which realizations people have personally experienced and what their emotional tagging is. Emotional tagging is the underpinning of experience effects in that personal experiences are more likely to be tagged than learned information. It also explains why an experience might have a long-term effect on some individuals, but not on others. In fact, two individuals may form opposite beliefs based on the same experience if it is tagged with positive emotions for one, and negative emotions for the other.

\footnotetext{
${ }^{1}$ We exclude 69 individuals from Berlin, who cannot be clearly assigned to East or West.
}

In this paper, we use exposure to a communist belief system as well as variation in its emotional tagging to predict long-run beliefs. We conjecture that people who experienced the communist system tagged with positive (negative) emotions hold more negative (positive) beliefs about capitalism, and are more (less) likely to think of communism as superior.

We exploit the regime change in East Germany (the former German Democratic Republic) from communist to capitalist, and show that emotional tags tied to the communist experience shape East Germans' beliefs about communism and capitalism in the long-term, even though the communist regime collapsed and a capitalist system was established. Thereby, we introduce the idea of emotional tagging from Psychology and the Neurosciences (cf. also Bergado, Lucas and Richter Levin (2011), Dolan (2002)) to the field of economics.

\section{Data}

\section{A. Survey}

We conduct two representative surveys with the German polling institute Norstat. The first survey was conducted among 1,598 Germans (246 in the East and 1,283 in the West) in July 2018. ${ }^{1}$ Respondents are on average 49 years old 
(ranging from 18-87), and $51 \%$ are female. The average respondent reports a monthly net income of 1,500-2,000 Euro, and has at least a high school degree. Respondents were asked about several statements. We focus on the following ones, which contrast capitalism and communism:

A) The economy only works if organized as 1) definitely capitalism, 2) rather capitalism, 3) rather communism, 4) definitely communism.

B) If it was possible to realize the socialist idea, I would prefer it: 1) definitely not, 2) rather not, 3) rather yes, 4) definitely yes.

C) Capitalism should be curtailed: from 1) definitely not to 4) definitely yes.

D) Under capitalism, the rich keep getting richer and the poor poorer: from 1) definitely not to 5) definitely yes. ${ }^{2}$

The second survey was run among 1,600 East Germans in December 2018. We conducted it exclusively in the East and recorded the county of residence in order to explore (regional) variation in emotional tagging of the communist experience. Respondents are on average 46 years old (ranging from 18-69), and 50\% are female. The average respondent reports a monthly net income of 1,500-2,000 Euro, and has at least a high school degree. In addition to

\footnotetext{
${ }^{2}$ Wording differed slightly between Surveys 1 and 2. In C), we used "abolished" in Survey 1 and "curtailed" in Survey 2, and in D), we used the "social market economy" instead of "capitalism."

${ }^{3}$ This question is based on a statement in Marx (1867).
}

questions A) to D), respondents were asked whether they agree (from 1) definitely not to 4) definitely yes) with the following statement:

E) Profits in the form of interest and yield take something away from employees, who could otherwise receive higher pay: ${ }^{3}$

Respondents are also asked about the statement "Religion is the opium of the people" (from 1) definitely not to 5) definitely yes), and whether their living standard since Reunification has 1) improved, 2) deteriorated, 3) stayed the same.

\section{B. Positive and negative emotional tags}

To proxy for emotional tags, we use regional and individual variation in the exposure to GDR success in sports and in the suppression of religion. ${ }^{4}$ The GDR regime regarded athletic prowess as an important tool to prove their superiority to Western capitalism, and celebrated Olympic medalists as national heroes. We use two proxies for positive emotional tagging: (1) residence in a county that was home to an Olympic gold medal winner; (2) survey responses indicating the belief that the GDR was stronger than the FRG in sports, particularly in Olympic Games.

The communist doctrine saw religion as a suppression tool of the ruling classes (Lenin

\footnotetext{
${ }^{4}$ We do not use other variation, e.g., in Western TV reception (used in Laudenbach, Malmendier, and Niessen-Ruenzi (2018) and Kern and Hainmueller (2009)) since we do not know respondents' ZIP code.
} 
(1905)). However, some GDR regions had a long tradition and cultural affinity to their churches, and suffered under the religious oppression of the communist regime. We use two proxies for negative emotional tagging of communism: (1) residence in a region where the Catholic Church was particularly strong, ${ }^{5}$ (2) survey responses indicating disapproval of Karl Marx' well-known statement that religion is the opium of the people (Marx 1843).

\section{East versus West Germans}

We first compare East and West Germans and examine the long-term impact of "living under communism" on beliefs. Germany is a unique testing ground as communism was imposed on East Germany by the Soviet Union and its Allies, but reunified thirty years ago. Thus, people today live under the same economic system, the same jurisdiction, and have access to the same social security system.

Our first survey reveals a higher fraction of East Germans having more positive beliefs about communism. As shown in Figure 1, more East Germans think that a communist economy works better, that capitalism makes the rich people richer and should be curtailed, and that the socialist idea should be made reality. These

\footnotetext{
5 "Catholic places" are counties that maintained a high level of catholic religiosity during the GDR and still do so today, according to the Konrad Adenauer Foundation (http://www.kas.de/wf/de/71.6604).
}

results hold in a multivariate ordered logit model, controlling for respondents' age group, income bucket, gender, education, employment status and self-assessed living standard.

This finding is remarkable since $74 \%$ of East Germans indicate (in our second survey) that their living standard has (weakly) improved since Reunification. On average, living under communism tilts peoples' beliefs about communism upwards in spite of their experience with its everyday hardship: per-capita GDP was less than half of the FRG (14k vs. $36.2 k$ Deutsche Mark), and fewer East Germans owned a car (52\% vs. 94\%), telephone (9\% vs. $98 \%)$, or TV (52\% vs. $94 \%){ }^{6}$

\section{Within East: Emotional tagging of communist experience}

The emotional-tagging hypothesis posits that East Germans with positive tags of their communist experience hold different beliefs about communism than those with negative tags.

We estimate an ordered logit regression with the same dependent and the same control variables, and add proxies for negative and positive emotional tags as explanatory variables.

In a first set of regressions, we examine whether survey respondents who live in the

\footnotetext{
6 de.statista.com/statistik/daten/studie/249689/umfrage/vergleichvon-west-und-ostdeutschland-vor-der-wiedervereinigung
} 
same county as an Olympic gold medal winner of the GDR (18\% of respondents) or who state that they think the GDR was superior in terms of sports (62\% of respondents) have more positive beliefs about communism. These variables should be unrelated to wealth differences or other cofounding factors. Panel A of Table 1 shows that, in both cases, East Germans with positive sports "experiences" have significantly more positive beliefs about communism today. They are more in favor of a communist economic system and making the socialist idea reality; more likely to prefer the abolishment of capitalism; and more likely to believe that capitalism makes the rich richer and the poor poorer. They also have negative attitudes towards interest and yield income, which are associated with capitalism. For the survey-based proxy, all of these differences are statistically significant at the $5 \%$ level or higher. Results are statistically weaker, but similar for the regionbased proxy. Relative to the mean, individuals who think that the GDR was superior in sports are $2.0 \mathrm{pp}$ less likely to state definitely capitalism (mean: 11.3\%), 2.7 pp less likely to state rather capitalism (mean: 47.3\%), 3.5 pp more likely to state rather communism (mean: $35.1 \%$ ), and $1.2 \mathrm{pp}$ more likely to state definitely communism (mean: 6.5\%).

To examine the impact of negative emotional tags on East Germans' beliefs about communism, we use cross-county variation in the strength of the Catholic Church at GDR times ( $10 \%$ of our respondents live in catholic places) and survey-based variation in disapproval of the statement that religion is the opium of the people (mean score: 3.00 on the 1-5 scale).

Panel B shows that East Germans whose experiences with communism are likely to be tagged with negative emotions due to their religious beliefs have more negative beliefs about communism today: They are less in favor of a communist economic system a realization of the socialist idea; less likely to prefer the abolishment of capitalism; less likely to believe that capitalism makes the rich richer and the poor poorer; and have less negative views on interest and yield income. All results (except for the communist economic order) are significant at the $1 \%$-level for the survey-based proxy, and similar albeit statistically somewhat weaker for respondents living in religious counties. Relative to the mean, individuals who live in a Catholic place are 4.1pp more likely to lean towards definitely capitalism (mean: 11.3\%), 5.5 pp more likely towards rather capitalism (mean: 47.3\%), 7.1 pp less likely rather communism (mean: $35.1 \%$ ), and 2.5 pp less likely definitely communism (mean: 6.5\%). 


\section{Conclusion}

Experiencing a communist system has longterm effects on beliefs about the benefits of communism, even after the communist system is overthrown. The experience of living under communism seems to be deeply anchored in peoples' memories. Positive and negative emotional tags strongly affect the pro- or anti-communist leaning. The emotional tags seem hard to reverse even many years later.

\section{REFERENCES}

Barberis, N., R. Greenwood, L. Jin, and A. Shleifer. 2018. "Extrapolation and Bubbles", Journal of Financial Economics, Vol. 129, 203-227.

Bergado, J.A., M. Lucas, and G. Richter-Levin. 2011. "Emotional tagging - A simple hypothesis in a complex reality" In Progress in Neurobiology. Vol. 94, 64-76.

Dolan, R.J. 2002. "Emotions, Cognition, and Behavior”, Science, Vol. 298, 1191-1194.

Frey, U. and R. G. Morris. 1997. "Synaptic tagging and long-term potentiation", Nature, Vol. 385, 533-536.

Fuster, A., D. Laibson, and B. Mendel. 2010.

"Natural Expectations and Macroeconomic Fluctuations", Journal of Economic Perspectives, Vol. 24, 67-84.

Hamman, S.B., T.D. Ely, S.T. Grafton, and
C.D. Kilts. 1999. "Amygdala activity related to enhanced memory for pleasant and averse stimuli”, Nature Neuroscience, Vol. 2, 289293.

LaBar, K.S., and R. Cabeza. 2006. Cognitive neuroscience of emotional memory, Nature, Vol 7., 54-64.

Laudenbach, C., U. Malmendier, and A. Niessen-Ruenzi. 2018. The Long-lasting Effects of Experiencing Communism on Financial Risk-Taking, Working Paper.

Lenin, W. 1905. Sozialismus und Religion, in: Lenin Werke Band 10. eds.1959 Berlin: Dietz.

Malmendier, U. and S. Nagel. 2011. Depression Babies: Do Macroeconomic Experiences Affect Risk Taking?, Quarterly Journal of Economics, Vol. 126, 373-416.

Malmendier, U. and S. Nagel. 2016. "Learning from Inflation Experiences", Quarterly Journal of Economics, Vol. 131, 53-87.

Malmendier, U., S. Nagel, and Z. Yan. 2018. „The Making of Hawks and Doves: Inflation Experiences on the FOMC",NBER Working Paper No. 23228.

Marx, K. 1843. Zur Kritik der Hegelschen Rechtsphilosophie. Einleitung. MEW Bd. 1. Moncada, D., F. Ballarini, M. C. Martinez, and H. Viola. 2015. "The Behavioral Tagging Hypothesis and Its Implications for Long- 
Term Memory Formation", in: Synaptic Tagging and Capture, Springer Science+Business Media, New York.

Richter-Levin, G., and I. Akirav. 2003. Emotional tagging of memory formation - in the search for neural mechanisms, Brain Research Reviews, Vol. 43, 247-256.

Talarico, J.M., LaBar, K.S., and D.C. Rubin. 2004. Emotional intensity predicts autobiographical memory experience, Vol. 32, 11181132.

Tversky, A., and D. Kahnemann. 1974. "Judgment under Uncertainty: Heuristics and Biases", Science, Vol. 185, 1124-1131. 


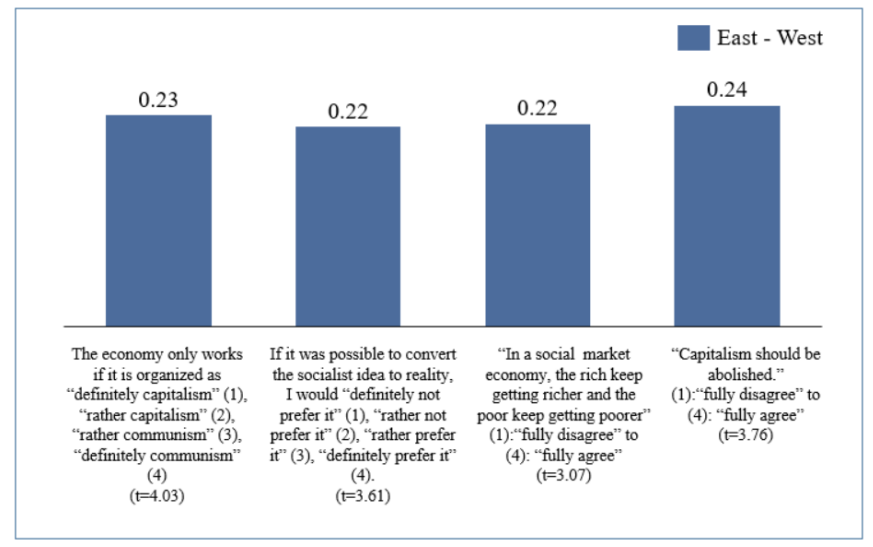

FIGURE 1. DiFFERENCES IN BELIEFS ABOUT COMMUNISM BETWEEN EAST AND WEST GERMANY

Note: This figure shows results from a representative survey on beliefs about communism conducted by the authors via the opinion poll institute Norstat in July 2018 among 1,598 Germans. The survey includes 1,283 West Germans, 246 East Germans, and 69 individuals from Berlin, who were excluded from the analyses. The graph shows means differences between East and West Germans in answers to the 4 questions depicted below the bars. T-stats for two-sided t-tests are provided in parentheses.

TABLE 1-EMOTIONAL TAGS AND BELIEFS ABOUT COMMUNISM

\begin{tabular}{lccccc}
\hline & $\begin{array}{c}\text { Pro commu- } \\
\text { nistic eco- } \\
\text { nomic order }\end{array}$ & $\begin{array}{c}\text { Pro socialist } \\
\text { idea }\end{array}$ & $\begin{array}{c}\text { Abolish } \\
\text { Capitalism }\end{array}$ & $\begin{array}{c}\text { Capitalism good for } \\
\text { rich only }\end{array}$ & $\begin{array}{c}\text { Negative attitude } \\
\text { towards interest } \\
\text { and yields }\end{array}$ \\
\hline Panel A1. & $0.35^{* * *}$ & $0.31^{* * *}$ & $0.29^{* *}$ & 0.14 & 0.08 \\
Olympic Gold Medal & 2.98 & 2.70 & 2.41 & 1.13 & 0.64 \\
\hline Panel A2. & $0.21^{* *}$ & $0.42^{* * *}$ & $0.22^{* *}$ & $0.58^{* * *}$ & $0.22^{* *}$ \\
GDR was strong at sports & 2.02 & 4.15 & 2.14 & 5.59 & -2.25 \\
\hline Panel B1 & $-0.43^{* * *}$ & $-0.31^{*}$ & -0.13 & $-0.34^{* *}$ & $-0.29^{*}$ \\
Religious (Catholic) Place & -2.73 & 1.94 & -0.88 & -2.15 & -1.77 \\
\hline Panel B2 & -0.04 & $-0.25^{* * *}$ & $-0.26^{* * *}$ & $-0.12^{* * *}$ & $-0.19^{* * *}$ \\
Disagreement: Religion is the opium of the people & -0.94 & -6.03 & -6.06 & -3.23 & -4.18 \\
\hline & & & & 1,600 & 1,600 \\
\hline
\end{tabular}

Notes: All Columns of this table present results from ordered logit regressions with beliefs about communism being the dependent variables. The wording of the questions in described in the Data Section. Each line (Panel A1-B2) results from a separate regression. Olympic Gold Medal is a dummy variable equal to one if an individual's residence is in a county that was the home of an Olympic gold medal winner, GDR was strong at sports is a dummy variable equal to one if an individual's survey response indicates that she beliefs that the GDR was stronger in sports than the FRG, Religious (Catholic) Place is a dummy variable equal to one if an individual's residence is in a region where the Catholic Church was particularly strong in GDR times, Disagreement: Religion is the opium of the people is an individual's survey response, where a higher value indicates disapproval of the statement that religion is the opium of the people (1-5 scale, $1=$ definitely agree, $5=$ definitely disagree). Standard errors are robust, z-scores are provided below coefficients. *** Significant at the 1 percent level. ** Significant at the 5 percent level. * Significant at the 10 percent level. 